Bogusława Bodzioch-Bryła*

Jesuit University Ignatianum

\title{
FROM AN E-NARRATIVE POEM TOWARDS AN INTERACTIVE WORK OF ART. MEDIA CONVERGENCE ILLUSTRATED WITH DOWN BY ZENON FAJFER AND THE SURPRISING SPIRAL BY KEN FEINGOLD
}

\begin{abstract}
The text, using the example of a work belonging to the literary style (Spogladajac przez ozonowa dziure [Detect Ozone Hole Nearby] by Zenon Fajfer) and the interactive art (the installation The Surprising Spiral by Ken Feingold) analyses the idiosyncracy of works positioning themselves at the borderland of media and literature, works both literary (textual, narrative and poetic) as well as media ones (changeable, iconic, set in a computer program, double-indirect), paying attention to the meaningfulness of the disciplines borderland (in this case literary and media studies). The author stresses the reasonableness of the question asked by Katarzyna Bazarnik, whether, by accident, the "Darwinian" evolution of species continues. In the author's opinion, based on her observation of works belonging to the literary style and the discussed work The Surprising Spiral by Ken Feingold, this question should get a positive answer. And possibly, as an effect of initiation, which has already happened, we will soon be entering the museum-gallery space not only in order to look but also to read.
\end{abstract}

Key words: liberature, Zenon Fajfer, Ken Feingold, borderland of media and literature, new media

The sheet of paper is not transparent, not in the least. This is only an illusion. We can no longer pretend that it is not here. It is. It has always been. It was and it had a nice smell. If I wanted a transparent page, I would use a transparent sheet.

* Institute of Culture Studies, Jesuit University Ignatianum in Krakow, Kopernika 26, 31-501 Krakow, e-mail:bogusiabb@interia.pl 
If I want a fully transparent page, I will print my text on a transparency and bind it in glass. The text will hover in the air, and the reader will be able to look at its members as if (possibly) God looks at us through the ozone hole.

What will I bind it in? In glass? Why not? Who said that a book must always look like «a book»? After all, this is only a convention that everybody follows automatically. [...] The book may even look like a bottle. What's more, it may be a bottle. But Eyeing Like Ozone Whole (2004) is a book like any other. But a book that cannot look otherwise. Because its form is dictated by the text. [...]

The creative act (often) begins from reflection on the structure of the book, and the act of reading (always) begins from taking the book in hand. A different book structure is tantamount to a different physics. The invisible text is meta-physics. Somewhere in between there is the reader who learns to read anew. (Fajfer 2010: 107-109).

This is what the introduction to the text discussing the issue of changes in a literary work of art at the turn of the 21 st century ${ }^{1}$ might be but for the fact that the artists, changing the physical form of a book, moved one step forward. Zenon Fajfer performed a contamination of a literary work of art having certain properties typical for e.g. the World Wide Web, while Ken Feingold inserted a literary text and the form of a codex into the boundaries of an interactive installation-work. The following text concentrates on two, in my opinion, tightly related works: the electronic version of Zenon Fajfer's DOWN published on the CD Primum Mobile attached to the paper volume ten letters containing versions of poems prepared in the form of an audiovisual presentation as well as on the interactive and at the same time deeply narrative example of a work of art - Ken Feingold's installation entitled The Surprising Spiral.

\section{A few words about the term convergence}

The conflict of two presently observed culture trends - convergence and participative culture - has changed the world of media and will certainly define its development over the next decades - Mirosław Filiciak writes (Filiciak 2006: 170). Media scholars have already been stressing the com-

1 And considering some experiments of the group OPOJAZ representing Russian formalism, also at the turn of the 20th century. 
plexity of the convergence phenomenon resulting in multi-faceted understanding of it for the last few years.

Fragmentation seems in some way to be one of the important features of new media. Yet at the same time one of the buzzwords of the new media explosion has been 'convergence' - the idea that at some point the technologies of media would all come together. Television, online video delivery, Internet communications and telecommunications combined in one 'black box' that will look something like a phone. However this vision has been widely challenged as devices and platforms have proliferated and instead content has converged (see Jenkins 2006: 15). Convergence however has at least two other meanings in this context. The first is the merger of media corporations in an attempt to provide a horizontal integration of different media products across a range of platforms. Thus the acquisition of MySpace by Rupert Murdoch's Fox Interactive in 2005 means not only that Fox have a foothold in the social networking market but that they can find new markets for the Fox back catalogue online as well as using the social network as a site for the development of new media products which may have a life in TV and cinema. 'Win / win' situations. (Lister, Dovey, Giddings, Grant, Kelly 2009: 202).

The conclusion drawn from these observations could be that the phenomenon of convergence may be found not only in the process of various media joining but also, and first of all, in the consequences of the joining, i.e. in the emerging of new and so far non-existent qualities.

Henry Jenkins significantly extends the meaning of the term, stating that the convergence phenomenon should be related to the mental state of contemporary culture participants who live in the world determined by new technologies transforming.

[...] the convergence is most importantly occurring not in the labs of technologists or the boardrooms of corporations but in the minds of the audience. It is we who are convergent - moving freely across a range of media platforms making connections between story worlds where the convergent activity has to do with the ways we make meaning of a fragmented media landscape, «convergence represents a cultural shift as consumers are encouraged to seek out new information and make connections among dispersed media content (Jenkins 2006: 3).

This is all very contradictory - we seem to be living through a period where the conflicts and opportunistic alliances of business interests produce a very dynamic system in which we experience fragmentation and convergence occurring concurrently. It is as if we are experiencing centripetal and centrifugal forces as outcomes of the same rapidly spinning wheel of media business and innovation. We can explain this in part by reference 
back to Anderson's Long Tail idea. The big media businesses who produce the 20 percent of products commanding 80 percent of sales at the head of the demand curve are not going away". (Lister, Dovey, Giddings, Grant, Kelly 2009: 202-203).

Some researchers signalise a new type of threat brought about by the discussed phenomenon:

Convergence can be understood as a way to bridge or join old and new technologies, formats and audiences. Such cross-media joining and borrowings may feel disruptive if we assume that each media has a defined range of characteristics or predetermined mission. Medium-specific approaches risk simplifying technological change to a zero-sum game in which one medium gains at the expense of its rivals. A less reductive, comparative approach would recognise the complex synergies that always prevail among media systems, particularly during the periods shaped by the birth of a new medium expression(Jenkins, Thornburn 2003: 3).

In scientific literature also general-culture convergence consequences as well as the necessity to change certain habits and to create new tools adequate for examining and describing new culture qualities created as a result of convergence get stressed:

The old either-or oppositions (co-optation vs. resistance) have long dominated debates between political economy and cultural studies. Approaches derived from the study of political economy may, perhaps provide the best vocabulary for discussing media convergence, while cultural studies language has historically framed our understanding of participatory culture. Neither theoretical tradition, however, can truly speak to what happens at the intersection between the two (Jenkins 2003: 292).

Another fact pointed at is that the emergence of the convergence phenomenon forces the necessity of asking new questions concentrating on the peculiar nature of the old and new information and communication technologies (ICT):

We need, then, to ask a number of questions of the modernist and avant-garde calls for new media to define itself as radically novel. Do media proceed by a process of ruptures or decisive breaks with the past? Can a medium transcend its historical contexts to deliver an 'entirely new language'? Do, indeed, media have irreducible and unique essences (which is not quite the same as having distinguishing characteristics which encourage or constrain the kind of thing we do with them)? These seem to be especially important questions to ask of new digital media which, in large part, rely upon hybrids, convergences and transformations of older media. (Lister, Dovey, Giddings, Grant, Kelly 2009: 62). 
These questions turn out to be important also in relation to works of art and the especially interesting conclusions seem to be the ones based on the observation of works which use the convergence phenomenon in order to arise in a particular form - an entity happening at the borderland of a literary and media text. Maryla Hopfinger in her book Literatura a media. Po 1989 roku (Hopfinger 2010), mentioning the literary context of media convergence, writes about a literary book moving beyond its traditional structure and about looking for new media for the content layer, first in the traditional form and then as new information and communication technologies, i.e. about literary-formal experiments which do not constitute differentia specifica of our time but reach back into the history of a literary book. The phenomena sources, according to Hopfinger, brought about formal experiments, which vividly intensified in certain moments of the history-literary and history-cultural process. Summing up the change which happened in the position and reception of literature after the breakthrough of 1989 the researcher stresses that the contemporary communication scene is cumulative while the dominance of audiovisual messages does not exclude the functioning of the earlier shaped forms of expression. However, it changes their place in the new configuration and the functions which they have today. It is thus impossible to claim that we are dealing with a break with communication experiences. There is a law of continuity and change in the way culture functions and the law expresses itself at the so called communication scene where all earlier forms and ways of communication between people meet: media as well as all the old and new communication practices - face-to-face communication, press and the radio, the cinema and television, painting and music, literature and television, professional, amateur, analogue and digital photography, a comic and postcards, various types of records, landline and mobile phones, computers and the Internet. These and other still new media and practices join those already present ones on the scene while the old ones usually disappear (Hopfinger 2010: 22). 


\section{Literary consequences of media convergence, i.e. about the possible reception of an e-narrative poem and problems related to $i^{2}$}

Zenon Fajfer, the author of Detect Ozone Hole Nearby, exploits the possibilities offered by a hypertext strikingly cautiously, choosing only those which best harmonise with the idea his poetry contains ${ }^{3}$. Let us analyse the way the poem we are concerned with emerges in front of a reader's eyes: at first, four subsequent letters appear on the screen and constitute the word DOWN. Each letter turns out to be the beginning of a next word. After the development of all of the letters an inscription appears which comprises the title of the work: Detect Ozone Hole Nearby. The title alternately winds up and unwinds on the screen getting farther or closer to the reader's eyes.

2 This article was originally written in Polish and referred to the Polish version of Zenon Fajfer's poem Detect Ozone Hole Nearby. The literary translation of the poem into English made by Katarzyna Bazarnik, Zenon Fajfer and Finn Fordham, in the official published version, significantly differs from the original poem. Even considering the peculiar process of translation, which follows its own rules and is never literal, it actually constitutes a separate literary work to a larger extent than a literal translation. Preparing the article for translation into English turned out to be more problematic than one might expect, therefore the author of the article (having consulted the translator of the article, the translator of the poem and also, indirectly, the author of the poem) has decided to use a risky solution and to explain it to the readers. Only this gives her a chance to show the attractive, emanative way of unveiling Z. Fajfer's poem in front of readers' eyes and of making its analysis and interpretation in a traditional article at the same time. So, in the main text of the article the print screens of the English literary translation of Fajfer's poem made by Katarzyna Bazarnik, Zenon Fajfer and Finn Fordham taken from the CD Primum Mobile were attached, which shows the electronic version of the poem, its appearance and changes in subsequent screens. The analytical and interpretational part of the article will be based on the word-for-word translation of the poem (made by Katarzyna Bazarnik) which will consequently be placed under some print screens (because this basic version of the poem is the subject matter of the article). This "literal" translation has never been published before and was used only as a draft for preparing the literary translation.

The author would also like to thank Katarzyna Bazarnik and Zenon Fajfer for giving her access to the aforementioned close to the original version of the poem translation and for their permission to publish it in this article.

3 It is undoubtedly difficult to give an account of the process of "happening", "becoming" or rather the emergence of the discussed work in the form of a traditional description because it is difficult to cite this transforming unity. So in order to make the picture of the piece and its appearance on the screen at least a little bit clearer the most convenient solution is to make print screens of the poem. 
Detect Ozone Whole Nearby

Next, gradually, a text appears on the screen and it then covers its whole space creating a record:

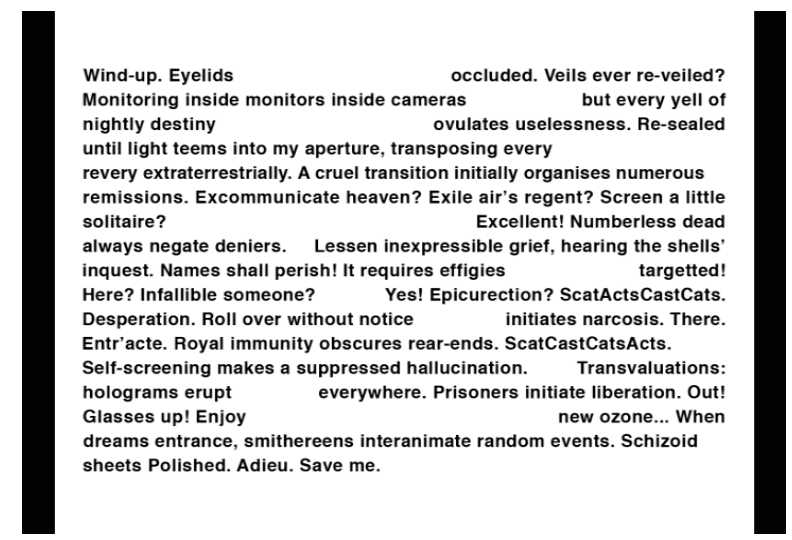

Photo. 3. Detect Ozone Hole Nearby

Over./Done./Finished. Lower the eyelids./Close the eyelids. Once again? From one screen/monitor to another. Taking off of the curtains. Or a scream. But. Futile despair. Yapping of fate and time. A hermetic case/glass box (?). Until someone opens it. Disperses the dream. Fills in the skyling's ${ }^{4}$ eye with the breath. In order for it to see to dead initials. Or in order for it to smash the screen. Who would dare smash the screen/monitor? Hide somehow? Beg/prey/refuse mercy in another voice? ${ }^{5}$ Offend the majesty of the treacherous screen? Screw the fun of playing with puppets? What finesse! The spring cull, an act of inexpressible altruism.

4 A pun on "niemowle" = a baby, and "niebo"= "sky, heaven"

5 Another fantastic pun on the phrase "łaski odmawiac", which here means "refuse mercy" and "say prayers" or rather "prey grace/mercy" 
Find gun shells. Or [finger]prints. Proof [to be used] for defending the framed one, irrefutable/unquestionable alibi. Does the barrel bluff? Wound the sniper's eyes ${ }^{6}$. Now! AktTakTkaKat ${ }^{7}$. Will you hit the target, the infallible being? [So exciting that] you have got an erection/epicurection? So little, but what torture/suffering. Or better without any warning. TkaTakKatAkt. Entr'cte. Love, lowe, lohe, loshe ${ }^{8}$. Covering naked arses with [the privilege of] immunity. Emotional interpretation. Grow indifferent, distance oneself. Another screen/monitor: I am a spectator/viewer.

An eruption of suppressed fantasy. Reverse parts/roles. Are there any other parts? The victim becomes a tyrant, the director an ordinary actor, the walk-on a cameraman. Or a non-engaged screenaziwriter. Stop the camera! A sip of refreshing ozone.

Scenario three, the aleatoric one. The throne of the skyling, an interactive scene of nappy changing. Adieu. Before they will wipe their arse with me. Or you'd better put the bottle away. Here. Or perhaps there. Anew. And? And nothing? Rather unimpressive acting/playing. The final episode. You come up and push the atelier bottle. And set me free?

[Katarzyna Bazarnik, Literal translation of Detect Ozone Hole Nearby, The visible upper layer of the text. A draft of the literal version of the translation of Detect Ozone Hole Nearby, an equivalent of the third screen (Photo 3)].

The next lines of the created work get bolded and overshadowed. Afterwards, some characters disappear and, in consequence, the screen looks like this:

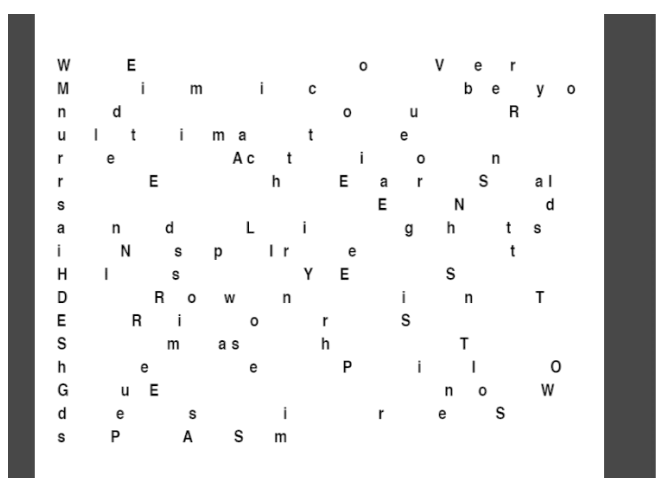

Photo 4. Detect Ozone Hole Nearby

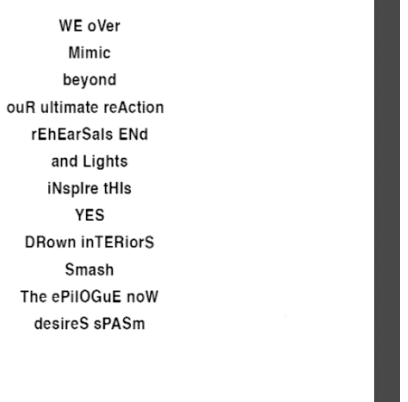

Photo 5. Detect Ozone Hole Nearby

6 In the original a pun "otrzy": this sounds like "oczy" = eyes, but the spelling indicates $\mathrm{O}_{3^{\prime}}$ i.e., "O three", or the chemical formula for ozone.

7 Onomoatopeic transformation of 3 letters that form 4 words; the sound effect and the anagrammatic transformation are more important than sense.

8 Another pun on the word "milosc" =love. $\mathrm{Mi}=\mathrm{me}$, imlosc=them-love, namlosc=us-love. A bit like "history", "herstory", "theirstory", "ourstory". 
The widened text pulls itself together with a crash creating another record (Photo 5). At the moment when the text slides together a loud crash of broken glass can be heard.

The characters change their positions again, some of them disappear. The process is accompanied by the sound of glass pressed. Additionally, at the bottom right hand corner of the screen, a small, at first hardly visible red point appears. It grows creating an inkspot resembling a bloodstain. The spot grows while the next parts of the text disappear.
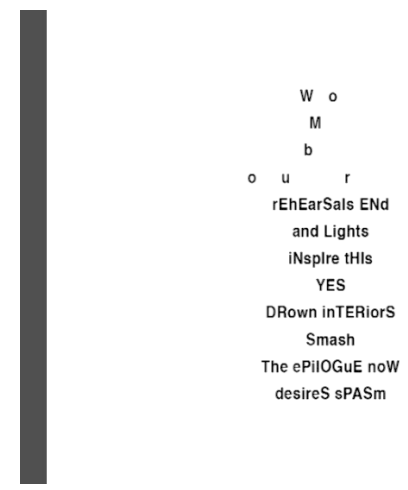

Photo 6. Detect Ozone Hole Nearby

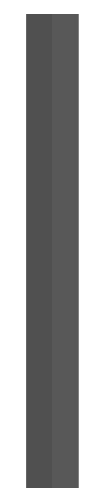

Photo.7. Detect Ozone Hole Nearby

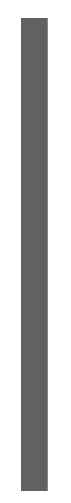

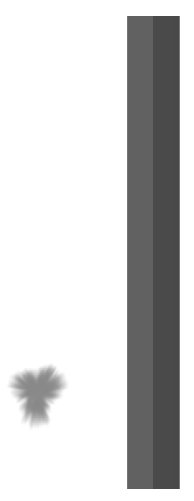

Photo 8. Detect Ozone Hole Nearby

\section{WoMb \\ our \\ rEaLitY \\ DiSTends}

The next step of transformation consists in the disappearing of the parts of the text which were written in lower case, in consequence of which the piece cramps till the moment the only thing left on the screen is the record "word" which gradually grows. 


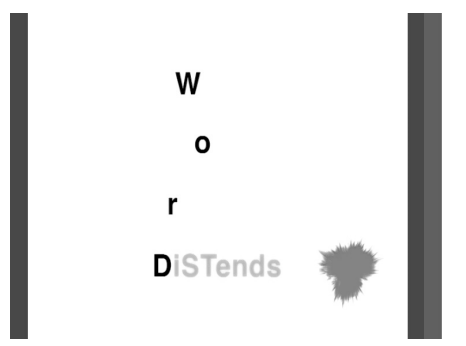

Photo 10. Detect...

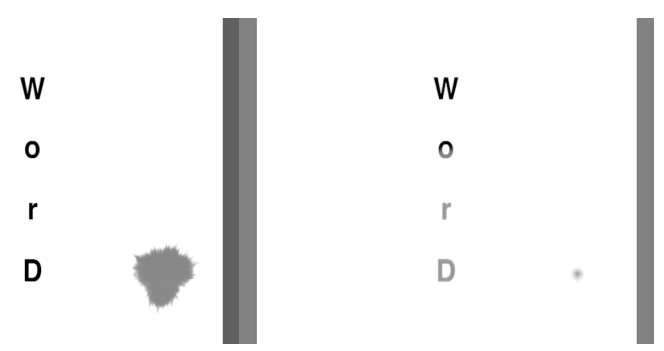

Photo 12. Detect

The red spot disappears, gradually colouring the text. Then the image itself disappears. In the final stage of the work transformations one can hear a female voice saying the expression "word".

It is necessary to add that the poem is accessible in two versions - an electronic one and the so called "material" one (entitled But Eyeing Like Ozone Whole) because it is rather difficult to differently label a piece written down on a rolled transparency and hidden in a bottle. The narrative poem in a bottle encompasses the content compatible with the record presented in the third slide mentioned (Photo 3), though with a slightly different layout. Also, the reader encounters a bigger difficulty than in the case of the e-narrative poem. One has to put an effort into reading the text in two ways: first, the full content printed on a transparency, and then, to put only the printed fonts together in a cohesive way, which turns out to be rather inconvenient for eyesight ${ }^{9}$.

It is difficult to escape the impression that it is impossible to attempt at interpreting a work without considering an author's explanation of its genesis and its final form despite the explanation being verbalised much earlier (long before the creation of the work, in the context of work on Oka-leczenie):

I wanted to describe the inexpressible: birth and death. I wanted to touch the very moment of leaving and arriving, the two poles of the great mystery.

What is, however, left to the writer who does not believe in the adequacy of language or the mere magic of silence? I was without an idea for a long time until 1993 when my father died and soon afterwards my son was born. For over

9 It is necessary to add that the text turns out not to be open to forms of use unpredicted by the author, e.g. an attempt at making a xerox copy of it for academic didactic use failed: the transparency broke in a few places and the poem fell into pieces. Moreover, it is really hard to take it out of the bottle in such a form. 
forty days I was living in a very strange state; I had an impression as if both of them were somewhere near. Finally, when I witnessed the birth, when I saw how that which had remained hidden for so long was emerging, I realized that my text should be hidden, too. I grew certain that neither death nor birth can be expressed in any other way, if they can be expressed at all.

I wanted to achieve perfect iconicity: I wanted to leave invisible for the reader what is invisible for us in everyday experience. I felt that only if I were to leave it like that, would it remain true. Invisible, and yet - let us add - seeable. [...] But this would only be possible with the use of some new dimension of text, some new form, a form that would enable words to be placed in another space, or to put it more precisely, enable the creation of that space.

I pondered on various ways of encrypting words [...]. The form that seemed so promising was something that I called emanationism: a kind of Chinese-box acrostic consisting of several layers of contracted text. It differs from the traditional acrostic insofar as one should read the initials of words (to be precise, all words from each subsequently emerging layer) and not only the first letters of each verse. All its layers form a multidimensional structure that can be reduced to a non-dimensional point.

How does it all work? Let us imagine a text whose words begin to disappear and only their initial letters stay. These letters form a new text out of which another text emerges through an analogous process, and the process continues up to the point when the whole work contracts to one word like an imploding star.

I would like to demonstrate how it actually works, using as an example «Ars poetica» (2004), a poem which I wrote ten years later, and which exists also in an electronic version". (Fajfer 2010: 97-98).

It is impossible to interpret the poem in a linear way. This kind of reading would impose a kind of interpretational violence. A strategy where certain flashes of meanings are caught and where some tracks initiated this way are continued as well as wondering through succeeding screens offered by the author seems to be more sensible. It is also suggested by the lyrical I writing: "Emotional interpretation. Grow indifferent, distance oneself".

We are dealing with a work about a poem emerging, about a narrative poem as well as a new life being born. The use of contaminations of terms "baby" (in Polish "niemowlęcie") and "sky/heaven" (in Polish "niebo") which creates a sort of pun on words "skyling" (in Polish "niebowlęcie") ("Fills in the skyling's eye with the breath") may be treated as an element stressing the divine particle in existence and a reference to the biblical creation act ("breathed into his nostrils the breath of life"), which may signalise a new life coming from the beyond. A significant role is also played by other contaminations in the poem: "lowe, lohe, loshe" ("Entr' cte. Love, lowe, 
lohe, loshe"), "screenaziwriter" ("The victim becomes a tyrant, the director an ordinary actor, the walk-on a cameraman. Or a non-engaged screenaziwriter"). It may be acknowledged that the neologisms created by means of contamination substitute a metaphor in Fajfer's writing. They compose a kind of screen within a screen and their ambiguity makes transfers between meanings. Those contaminations attract attention to the very issue of ambiguity, to the gradual meanings completion, to their overlapping, in a way heralding what will happen in a moment by means of screens changing and opening, completing the already existing contents and with new ones unveiling for the reader together with another sequence of images.

Fajfer juxtaposes two categories: ambiguity and the possibility of meaning extension described by the lyrical I as "taking off the curtains" against unambiguity, closure and limitation ("A hermetic case/glass box (?). Until someone opens it. Disperses the dream").

The openness of the narrative poem, visible in the transforming structure, is also signalised on the level of meanings of the work in the stressed changeability of roles between the sender and the receiver, the creator and the reader ("Reverse parts/roles. Are there any other parts? The victim becomes a tyrant, the director an ordinary actor, the walkon a cameraman. Or a non-engaged screenaziwriter. Stop the camera! [...] Scenario three, the aleatoric one. [...],/an interactive scene of nappy changing. Adieu...").

The clarity of the text got disturbed by the author in a controlled way. He introduced an element of chaos and mixing in order to point at the moment when the text stops having a meaning as a record and starts to have an effect as a visual whole (See photo 13).
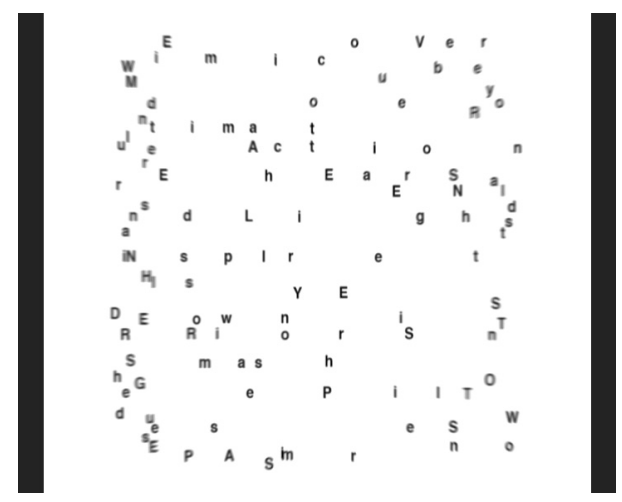

Photo 13. 
This is the moment when it is impossible to notice a written sense in the screen. It is only possible to look at the jumbled characters as at a picture, and let us repeat, at a picture of chaos. This state is an answer to the discomfort triggered by the feeling of suppression and constraint which should be overcome ("Futile despair. Yapping of fate and time. A hermetic case/glass box (?). Until someone opens it. Disperses the dream", "the majesty of the treacherous screen", "So little, but what torture/suffering"), which happens in the work in various ways and in its various layers (of reception and construction). We are facing a transition ("From one screen/monitor to another. Taking off of the curtains"), a smashing of a monitor ("Who would dare smash the screen/monitor?"), a systematic transformation of senses ("AktTakTkaKat - an onomatopoeic transformation of 3 letters that form 4 words in Polish, "Love, lowe, lohe, loshe"), an unexpected swapping of roles ("Another screen/monitor: I am a spectator/viewer. An eruption of suppressed fantasy. Reverse parts/roles. Are there any other parts? The victim becomes a tyrant, the director an ordinary actor, the walk-on a cameraman. Or a non-engaged screenaziwriter"). The consequence of such a liberation is the aforementioned eruption ("Or a scream/? [So exciting that] you have got an erection/epicurection, An eruption of suppressed fantasy/ You come up and push the atelier bottle. And set me free?") As well a temporary chaos and a division of meanings.

A full interpretation or explanation of the Web text can by no means be made because its inexplicability is made innate there by the author. Also its structure is in principle based on $i^{10}$.

\section{Literary and media qualities in an emanative poem}

The work may be considered important on the grounds of the medium Fajfer chose resigning from those he has used so far - the non-traditional and innovative ones in form, nevertheless placing themselves more on the side of the "old media" (where the meaning of the term must be separated from the one commonly used in media studies because the matter the artist

${ }^{10}$ One might certainly go further in analytical and interpretational action, however in the limited length of the article there would not be then enough space for mentioning other, equally important aspects of the work. Therefore the analysis and interpretation of the poem is deliberately left incomplete and open, with only certain interpretational threads outlined. 
used as the basis of his work, inter alia glass ${ }^{11}$ or paper ${ }^{12}$ used in an unconventional way, are undoubtedly special examples of untypical means of recording) and he uses an interactive carrier. It is the very carrier that another issue worth stressing can be ascribed to, because the artist, choosing an interactive medium, has decided, unlike one might assume, not to use all the possibilities it offers. He has not given up on an, in a way, traditional flat layout of the text on the page, using the branching structure of a hypertext ${ }^{13}$ only to a limited extent. This is one of the reasons why one should not use the expression "an open work" but rather "a half-closed work".

The duality of the work seems to be obvious - it is embedded in both literary and in media spheres as Fajfer's poem is a literary work of art happening at the borderland of media and literature. Apart from the determinants of its literariness and poeticality (artistic means, a poetic function) there are visible typical media qualities, just to mention a few: the dynamic changeability of the transforming message, its being iconic (the significance of a picture) understood on two levels: as creating a graphically meaningful whole out of letter characters (the shape of the record, especially with reference to photos $4,5,6,8,9$, and 11) but also as using graphic signs and pictures (e.g. the growing red spot, photos 6, 7, 8, 9, 10, and 11) or as the colouring expression "word" emerging while the red spot disappears (photo 11). The other media qualities are: basing the work in a computer program and its double indirectness made through a new medium ${ }^{14}$ (as a kind of double indirectness which reaches the level of the content of the work $)^{15}$.

${ }^{11}$ E.g. in the case of the material - glass edition of But Eyeing Like Ozone Whole (2004), as well as the second ("amended") edition in a carton pack (Fajfer, 2009)

${ }^{12}$ See e.g. Oka-leczenie by K. Bazarnik and Z. Fajfer. (Bazarnik, Fajfer 2009)

${ }^{13}$ Like e.g. Sławomir Shuty did (in his hipertextual novel Blok which may be read according to the topographic direction of the text (based on the structure of floors and flats his characters live in) or through classical hyperlinks; http://www.blok.art.pl/), by Radosław Nowakowski (in his novel Koniec świata według Emeryka), etc.

${ }^{14}$ In the case of Fajfer's poem one may ascertain that we are dealing not only with language double indirectness but also with an additional kind of complexity - a structure double indirectness which is not a binary structure but a rhizomatic or branching one. Therefore it is not enough to discuss only double indirectness but it is necessary to talk about double indirectness and densing or interweaving. Up to a point, because like I have stated before, Fajfer reduced the hypertextual character of the work for the sake of a certain, so to speak, controlled opening.

${ }^{15}$ Because traditional literature was also double indirect through the paper and print format but that double indirectness did not spread over the level of meanings of the work (only works belonging to the specific poetry group [calligrams], futurists' experiments and other references to them were an exception) and books were thought about in terms of content and meaning. 
Fajfer undertakes polemics with some of the new media qualities pointed by Lev Manovich (Manovich 2006: 91-118) ${ }^{16}$. It is hard to argue with the numerical representation, the issue of modular structure of individual objects or with transcoding but the issue of automation may be dubious here because Fajfer did not rely on a computer program in terms of creating the message. The reader can at most make the work run and is also able to stop it but eliminating human participation from the creative act or depriving the work of intentionality (at the creative process stage) is out of the question. The work was created as an intentional production and is an effect of the very intentionality. Fajfer's poem cannot exist in variations or in various versions (the recipient is not able to create variants of the literary message ${ }^{17}$ ) and will thus not become its creator or the creator's partner because a dialogue is possible only on the interpretational level (only its interpretations can be variable).

Discussing Fajfer's work it is possible to talk about, at most, an interesting dialogue of literature with new media, a certain kind of a literary romance which, taking the strength of fascination with media into consideration, starts to wear the characteristics of a strong relationship ${ }^{18}$.

${ }^{16}$ Describing the language of new media Lev Manovich mentions the following of its properties:

- numerical representation (all new media objects are numbers written in a digital form); a picture or a shape may be recorded as a mathematical function; the object may be algorithmically processed; they are programmable; objects here consist of 'discreet", discontinuous elements);

- structure modularity of objects (each of them consists of independent parts all of which consist of smaller, also independent elements and so on, up to the level of indivisible pixels, 3D points or textual characters. Removing one of the elements [adding a new one or an exchange] does not radically violate the whole message structure);

- automation (creating a message may, up to a certain extent, be given to e.g. computer programs without a direct human influence, which is a way of [partial] elimination of intentionality from the creative process);

- variability (fluidity, changeability); the final, once and forever fixed representation of the message does not exist. It is not like in a traditional written text, a classical film or video. Theoretically, countless variations may be created. They are message "variations" and a computer user entering the dialogue becomes a message creator and the creator's partner;

- transcoding (a certain "translation" of culture texts into the language understood by the computer; this way two levels influence each other - the computer and culture ones; a researcher does not exclude the option that the former influences the latter one: this is how e.g. new media genres or a new message content come into being and how the organisation of media understood as institutions changes);

${ }^{17}$ Unless we recognise the "material" version (a narrative poem closed in a glass bottle) and the electronic one as variations.

${ }^{18}$ Similar conclusions will refer to Fajfer's works Ars poetica and Immanent treatise 
To be specific, it must be admitted that some of the properties indicated by Manovich actually materialise only in the recipient's mind. Considering Fajfer's work as a whole and treating the work itself and the potential interpretations it generates as equally important, one might undoubtedly call it a new media work.

Fajfer exploits the possibilities offered by a hypertext extremely carefully, choosing only these which best correspond with the ideas presented in his poetry ${ }^{19}$. His work constitutes a clearly limited whole, each time "happening" the same way. It is spatial, however, in a totally different way. It is more, so to speak, going into itself or between particular levels (openings, screens) of the same text rather than between different texts constituting a whole. Anyway, there are no links between particular levels (screens) in the work; they may be read, contrary to appearances, according to the linear sequence of openings. The issue should not be understood in categories of a deficiency because this trick was used by the author on purpose and a structure thought-out this way goes hand in hand with the idea the poem contains or is even subordinate to it. The screen motif occurs in the text very often ("From one screen/monitor to another", "/in order for it to smash the screen", "Who would dare smash the screen/monitor?", "Offend the majesty of the treacherous screen?") - Fajfer writes and consistently starts making subsequent screens work showing the reader how one can see (read) the work in the original version ${ }^{20}$ and then in the one extended with other images. Each successive "opening" of the poem changes its sense and, significantly extending it, attracts attention to the aspect of speech which is absent in the preceding version.

${ }^{19}$ What proves that the author's choices are fully justified and deliberate is one of his statements explaining the reasons for using the emanative poem form. Fajfer writes: "it is wrong to treat emanationism simply as a writing technique. What is created through it is a totally new literary form whose structure is not semantically neutral (unlike, e.g. the structure of the sonnet), but pregnant with important meanings: from epistemological and ontological to cosmogonic ones. In emanational prose and poetry, every single letter of text is shown and seen from a new perspective; hackneyed words and motifs regain their freshness. Such notions as time, space, hero, plot, narrator and the lyrical «I» take on a totally new dimension in the process of literary emanation, writing off as fiction gloomy prophecies about the exhaustion of literature soaked in self-reflexivity. On the contrary, I believe that together with emanationism literature is entering a new, subtler phase of existence, and Oka-leczenie marks only the beginning of this process. When writers get used to this technique, when they familiarize themselves with its benefits and learn to overcome technical conditions, masterpieces will appear that are not dreamt of not only in philosophy. (Fajfer 2010: 40-41)

${ }^{20}$ Being aware that the term "original version" is not entirely adequate as there are no "next versions" but rather intersecting or overlapping levels or layers of the work. 
Even though the hypertext form used by Fajfer turns out to be closed (or, as it was said before, at most half-closed) by means of the aforementioned deliberate limiting, the work itself is left open. Moreover, this openness should be recognised as the crucial quality of that type of works. This is by no means a novelty in literature. A smaller or bigger element of openness has appeared in the most famous attempts at defining a literary (poetic) work as well as a work of art. Just to mention some examples - the notion of indefinite place used by Roman Ingarden, Umberto Eco's open work category or Robert Escarpit's theory of susceptibility to betrayal. In the light of these observations all efforts put into telling the whole truth about a poem seem to be interpretational violence. In the case of works using new media as a medium the aforementioned openness gains a more literal and radical character; it stops touching only the issue of the possibility of interpreting the tropes and the text itself and it starts to be proved by the structure of the work which stops being laminal (structuralism) and starts being hypertextual and rhizomatic, as the sense of the work got located in such an existence basis (a branching medium).

Where should one search for tools to interpret literary works settled at the literature and media borderland? In the theoretical tools resource of literary or media studies? A clear answer to this question does not exist. In principle - somewhere "in between". The essence of the problem is that the artistic matter has undoubtedly managed to get ahead of its description tools because in a theoretical description we are in a way still confined to the tools of literature and film studies. And considering the fact that film studies rely to a large extent on the literary work theory - the situation gets markedly limited.

Katrzyna Bazarnik, making her attempt at literary-theoretical extra defining of liberature, apart from the genre qualities typical for works belonging to this group, points at some properties located between the literary and media works ${ }^{21}$, i.e. the use of non-verbal and typographic means of expression subjected to the verbal expression and helping it; the spacial structure of the text, often resulting in an unconventional book form; iconicity, both pictorial and diagrammatic (iconicity of structures); self-reflexivity or metatextuality; hybridity/polimediality; interactivity and ergodic quality, i.e. a situation in which the reader determines the shape of narration; materiality; medium specificity (where exploiting specific features of a medium an intermedial translation is impossible since transporting the text onto a different carrier distorts the work) (Bazarnik 2010: 159-163).

${ }^{21}$ Emphasising, however, that the group of qualities is blurred, therefore to classify a work as liberature it is not necessary to identify all of them in a given work. 
"Would, then, ten letters be a model prototype of e-liberature, an example $[. .$.$] of usefulness of even this term, and does it mean that the$ "Darwinian" evolution of genres would be going on?" - Katarzyna Bazarnik asks (Bazarnik 2010: 163). Taking the work I am going to discuss in a moment into consideration, i.e. The Surprising Spiral by Ken Feingold - the answer to the question asked by her should probably be given a positive answer.

\section{The Surprising Spiral by Ken Feingold as an example of a total work falling between a work of art and a literary work ${ }^{22}$}

A work written by Ken Feingold in 1991 entitled The Surprising Spiral is an extremely interesting example of an artistic experiment constituting, in my opinion, an eminent example of old and new media convergence introducing, in effect, a new artistic and literary quality. The author himself writes about his work:

The Surprising Spiral is an interactive artwork, utilizing a computer controlled videodisc, computer graphics, digitized sounds and texts, and synthesized voices, embedded within sculptures. The work responds to the form of the viewer/ participant's engagement. The viewer's ability to interact and direct the flow of images and sounds allows him or her to "play" the piece, to seek or escape from finding a destination, or to enjoy its labyrinthine paths. There are two sculpture/interface objects through which a viewer can interact with the work. One is a large, hollow handmade book (13"x $\left.15^{\prime \prime} \times 6^{\prime \prime}\right)$ in which are encased replicas of human hands. In a cut out in the center of the cover is embedded a transparent touch screen, which appears to be the glass "cover" of the book. On this touch screen are fingerprints, placed above the fingertips of the larger hand within the book. When a viewer touches any of the fingerprints, various things can happen: there are always sound responses to these touches, usually speech; the video can change to another location in the world, or an animated text might be evoked. In any case, a turn is taken in the labyrinth ${ }^{23}$.

${ }^{22}$ The Surprising Spiral by Ken Feingold was also my analysis subject in my article Pomiędzy natura a simulacrum. O przekraczaniu natury w sztuce interaktywnej, na przykładzie dzieła The Surprising Spiral Kena Feingolda oraz instalacji Christy Sommerer i Laurenta Mignonneau where I paid attention to contemporary artists using elements of nature in the process of creating a work of art.

${ }^{23}$ See: http://wro05.wrocenter.pl/thesurprisingspiral_pl.php. The description comes from a website promoting the International Media Art Biennale Wroclaw 2005. Access date: 03.08.2012. 
The work has a complex cause and effect structure, and a touch that the viewer makes might have an immediate visual response, happen a short time later, or much later. I wanted these to mirror our daily cause and effect experiences. That is, sometimes we see the results of an action immediately, very soon, much later, etc. No two viewers will see the same flow of images or hear the same sounds in the same sequence, and the actions of previous viewers will also affect the structure found by another viewer. On the spine of the book is the title La Espiral Sorprendente, the title of the work in Spanish. It is homage to Borges and Paz, the writers who inspired this work.

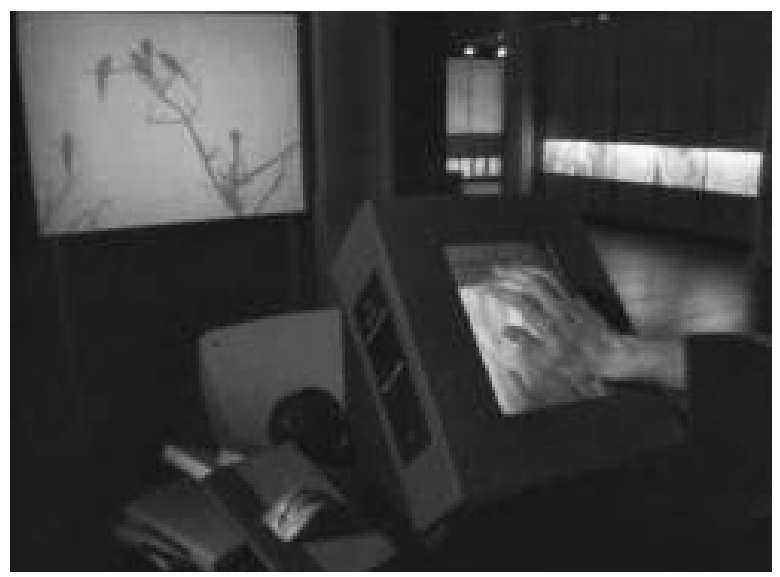

Photo 14. Ken Feingold, The Surprising Spiral (1991) ${ }^{24}$.

The other interactive object is also a book, an actual book of Octavio Paz, The Monkey Grammarian. Embedded in the cover of the book is a casting of a man's lips, and between the lips a faint red light glows. When a viewer holds their fingertips upon the lips, one hears texts from the book spoken aloud. When the hand is removed, the text ceases, and the mouth falls silent again. If no one does anything to interact with the work for a length of time, it follows a path of images that lead to one of the looped "nature" images. At this point, the work will also clear its memory of the touches previous viewers have made, and it begins anew when touched again. These objects are set upon furniture sculptures made by author, and these stand upon a painted wooden platform ${ }^{25}$.

\footnotetext{
${ }^{24}$ See: http://wro05.wrocenter.pl/thesurprisingspiral_pl.php. Access date: 03.08.2012.

${ }^{25}$ Ibid.
} 


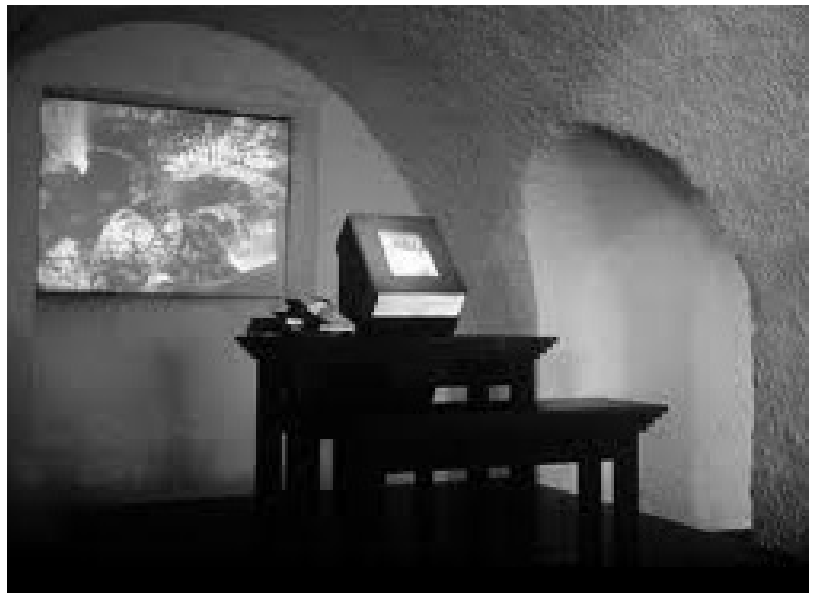

Photo 15. Ken Feingold, The Surprising Spiral (1991) ${ }^{26}$.

How to interpret such a work? According to Feingold's suggestions it may be stated that:

The work is about the simultaneous sensations of ecstasy and emptiness which arise from the labyrinthine nature of traveling, of being in motion; the mind reflecting upon itself and upon the organization of languages, thoughts and perceptions. Images flow from one place in the world to another, a continuous movement of the passenger, the one walking through, passing through; the view of the world along the path, with no end in mind. These are images that I recorded from 1979 to 1991, in the USA, India, Japan, Argentina, Thailand, Scotland, Sri Lanka, utterly without any conception of cinematic mise en scene. They are the remains, the visual and auditory residuum of what has been passed by, moved through. As a reverse side, moments of the camera's fixity which have observed what we think of as "nature", that is, time outside of our own determinations, events unfolding oblivious to human purposes, the temporal order which marks our own passage through time, whether we are in motion or not ${ }^{27}$.

Piotr Zawojski presented an interesting analysis of the installation. The researcher notices that it is just a model version of a realisation representing the first generation of artists attempting at creating an interactive narrative work (though not a linear or multilinear one) appealing through stories generated by interactors-users. Those stories cannot repeat, their sequenc-

${ }^{26}$ Photo source: http://www.medienkunstnetz.de/works/the-surprising-spiral/ Access date: 15.07.2012.

${ }^{27}$ Webpage source: http://wro05.wrocenter.pl/thesurprisingspiral_pl.php. Access date: 15.07.2012. 
ing is based on modules suggested by the artist but these modules may each time be randomly composed in the reception process. A narrative character is in this case a result of a certain kind of game a user participates in by means of interface(s). Referring to the mythical "book" of the world as a labyrinth, citing Borges and Paz - the writers under whose patronage the work was created, the artist designed a multithreaded, branching navigation route over pictures recorded during travels around the world, using also an excerpt of the feature film L'immortelle by Robbe-Grillet, some documents, commercials, computer animations, as well as various sound effects, words and passages spoken in several languages (Zawojski 2005) ${ }^{28}$. Some passages of El mono grámatico by Octavio Paz can be heard when the second interface is used. Zawojski stresses that, like in The Book of Sand by Borges, the travel here resembles a hypertextual navigation. Borges, creating the concept of an infinite book called it The Book of Sand because neither the book nor sand have a beginning or the end. "A line consists of an infinite number of points; a plane consists of an indefinite number of lines; a supervolume - of an infinite amount of a volume..." Borges writes and these words accurately characterise the idea behind Ken Feingold's work (Ibid.).

Jorge Luis Borges whose output Feingold refers to by means of placing the Spanish title on his own work, describes a "Total Book", a divine one which transforms into a monstrual or devilish one in the short story The Book of Sand. The description of it, stressing contradictions and its paradoxical nature, corresponds with the multiple dimensions of The Surprising Spiral:

It was a clothbound octavo volume that had clearly passed through many hands. I examined it; the unusual heft of it surprised me. On the spine was printed Holy Writ, and then Bombay.

«Nineteenth century I'd say», I observed.

«I don't know», was the reply.

«Never did know».

The characters were unfamiliar to me. The pages, which seemed worn and badly set, were printed in double columns, like a Bible. The text was cramped, and composed into versicles. At the upper corner of each page were Arabic numerals. I was struck by an odd fact: the even-numbered page would carry the number 40,514, let us say, while the odd-numbered page that followed it would be 999 . I turned the page; the next page bore an eight-digit number. It also bore a small

${ }^{28}$ http://www.zawojski.com/2006/04/19/galaktyka-post-gutenberga/. Access date: 15.07.2012. 
illustration, like those one sees in dictionaries: an anchor drawn in pen and ink, as though by the unskilled hand of a child.

It was at that point that the stranger spoke again. "Look at it well. You will never see it again". There was a threat in the words, but not in the voice. I took note of the page, and then closed the book. Immediately, I opened it again. In vain I searched for the figure of the anchor, page after page. To hide my discomfiture, I tried another tack.

«This is a version of Scripture in some Hindu language, isn't that right?»

«No», he replied.

Then he lowered his voice, as though entrusting me with a secret.

«I came across this book in a village on the plain, and I traded a few rupees and a Bible for it. The man who owned it didn't know how to read. I suspect he saw the Book of Books as an amulet. He was of the lowest caste; people could not so much as step on his shadow without being defiled. He told me his book was called the Book of Sand because neither sand nor this book has a beginning or an end».

He suggested I try to find the first page. I took the cover in my left hand and opened the book, my thumb and forefinger almost touching. It was impossible: several pages always lay between the cover and my hand.

It was as though they grew from the very book.

«Now try to find the end».

I failed there as well.

«This can't be», I stammered, my voice hardly recognizable as my own.

«It can't be, yet it is», the Bible peddler said, his voice little more than a whisper.

«The number of pages in this book is literally infinite. No page is the first page; no page is the last. I don't know why they're numbered in this arbitrary way, but perhaps it's to give one to understand that the terms of an infinite series can be numbered any way whatever».

Then, as though thinking out loud, he went on.

«If space is infinite, we were anywhere, at any point in space. If time is infinite, we are at any point in time».

His musings irritated me.

«You», I said, «are a religious man, are you not?»

«Yes, I'm Presbyterian. My conscience is clear.

I am certain I didn't cheat that native when I gave him the Lord's Word in exchange for his diabolic book». [...]

I showed no one my treasure. To the joy of possession was added the fear that it would be stolen from me, and to that, the suspicion that it might not be truly infinite. [...] I examined the worn binding and the covers with a magnifying glass, 
and rejected the possibility of some artifice. I found that the small illustrations were spaced at two-thousand-page intervals. I began noting them down in an alphabetized notebook, which was very soon filled. They never repeated themselves. (Borges; http://www.annecoale.com/web4pics/bookofsand.pdf).

An absurdity, a paradox, ("It can't be, yet it is" [Ibid.]) and an oxymoronic quality ("The number of pages in this book is literally infinite. [Ibid. Underlined by B.B-B.]) Are the categories linking both works in question and traceable both in the context of Feingold's work and Borges' prose. As one can see, the peculiarity of the book is stressed in the text in various ways. The artist offers a certain game with the reader, not only deconstructing the eternal truths, but also suggesting that the text of The Book of Sand should be read in a similar way: "I was struck by an odd fact: the even-numbered page would carry the number 40,514, let us say, while the odd-numbered page that followed it would be 999. I turned the page ..." - Borges writes transforming the sacred book into an infernal and "monstrual" one not only in the symbolic plane, through reversing the page number (999 changes into 666), but also in the mental one: "I felt it was a nightmare thing, an obscene thing, and that it defiled and corrupted reality. I considered fire, but I feared that the burning of an infinite book might be similarly infinite, and suffocate the planet in smoke" (Ibid.).

According to P. Zawojski, the work

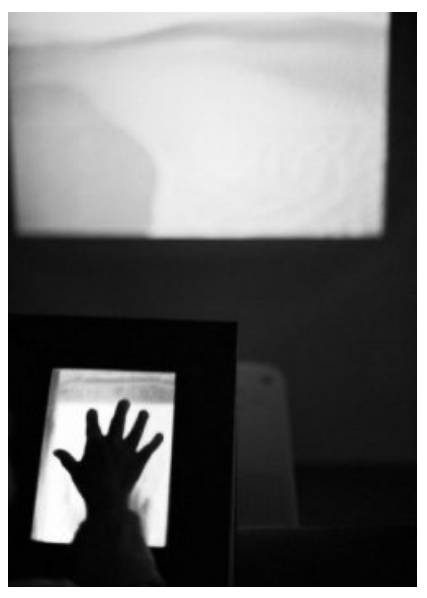

Photo. 16. Ken Feingold, The Surprising Spiral (1991) $)^{29}$ - installation The Surprising Spiral by Ken Feingold also refers to the problem of interface development, and, to be more specific, tactility. Faingold mentions that one of the reasons of his interest in touch screens was an inscription placed in a catalogue designed by Marcel Duchamp. It was a catalogue of an exhibition entitled Le Surréalisme prepared by Feingold and Andre Breton in 1947. On the cover of the book one could see an artificial woman's breast while on the reverse it was written in French Prerie de Toucher - Please touch... A physical relationship, closeness, a direct contact - this is a book moved into a technological

${ }^{29}$ A photo by Anna Mrogowicz from the vertical portal culture.pl: http://www.culture. pl/baza-sztuki-pelna-tresc/-/eo_event_asset_publisher/eAN5/content/wro-miedzynarodowe-biennale-sztuki-mediow. Access date: 15.07.2012. 
dimension. When touched it activates a totally new, labyrinthine and hybrid reality. But to make it open for us and to get immersed in it we must go through the experience of a book (Zawojski 2005).

The Surprising Spiral is a textual and narrative work and at the same time it is hypertextual and rhizomatic. Paying attention to its quite important quality (on wchich, to the same extent as on its physical materiality and audiovisuality, it is based) which is its language character, one might risk stating that we are dealing not only with a variation of a hypertextual, interactive and media work but, in the first place, a textual and literary one.
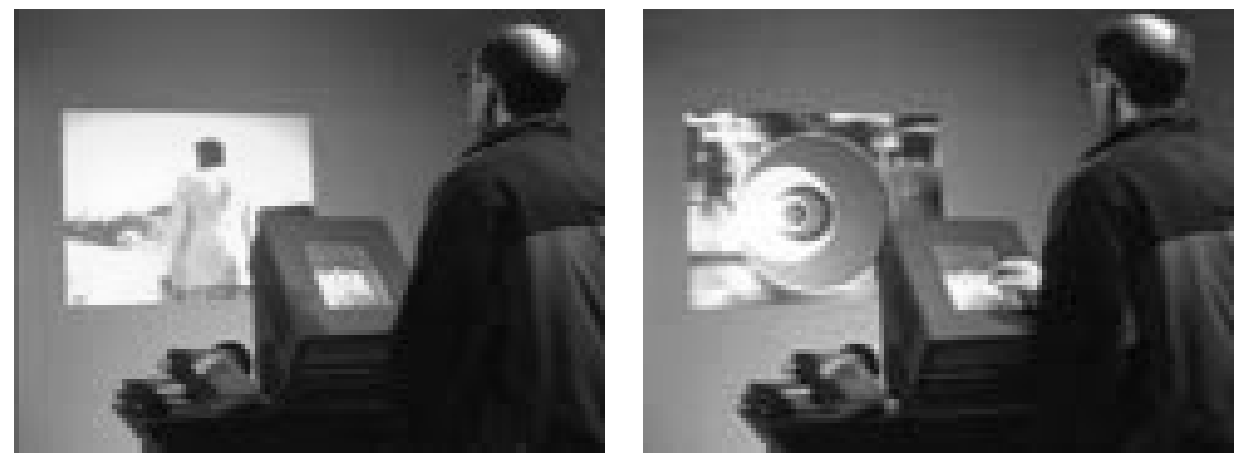

Photo 17 and 18. Ken Feingold, The Surprising Spiral (1991) $)^{30}$

Dorota Hartwich stresses the language-experimental aspect of the discussed object. In her report from an exhibition Inna ksiażka. Ksiażka i tekst poza ksiażka w dobie nowej komunikacji ${ }^{31}$ she emphasizes that a language experiment of this kind illustrates how:

language gets independent from reality, escapes from grammar rules, skips logic laws and functions according to its own principles. It is no longer a reflection of the world, it loses, as Michel Foucault would say, its transparence; signifiant leaves signifié, words - even if they enable us to see things through them - are not their «analogons». The tree I'm writing about is not the tree I see - says the

${ }^{30}$ The source of photographs: http://catalogue.nimk.nl/site/?page=\%2Fsite $\% 2$ Fart.php $\% 3$ Fdoc_id\%3D2813. Access date: 15.07.2012. See also the work documentation prepared by the author: http://catalogue.nimk.nl/site/?page=\%2Fsite\%2Fart.php\%3Fdoc_id\%3D2813. Access date: 05.09.2012.

${ }^{31}$ (which was held in May 2005 in Muzeum Narodowe in Wrocław as a special event of XI Międzynarodowe Biennale Sztuki Mediów WRO 05. (International Media Art. Biennale WRO 05). 
voice in Ken Feingold's installation The Surprising Spiral [...]. In his installation Feingold also liberates words [...]; the author of the work adopts a consciously developed artistic strategy [...]. Feingold emancipates a written word - a text, extracting it from its primary environment, i.e. from a book. He constructs an interactive book without a text..." (Hartwich) ${ }^{32}$

The text which is created by each subsequent interactor and all of them together because the former one can influence what the latter one hears or sees. "Feingold eliminated only written words from the book. Spoken words are present and function beyond the book - they can be, again through touching, «brought out» form the mouth replica placed on the authentic volume by Octavio Paz (The Monkey Grammarian). Random pictures of reality triggered by a hand movement are assigned to a text read aloud" (Ibid).

We are therefore dealing with a special kind of work placing itself at the borderland of mediality (installation work) and textuality (book work) with a form evading any attempts of defining or classifying. A media or multimedia work is based on an individually changed structure of an aesthetic situation. The elements involved in it are an interactive artefact (i.e. an object), and interactor (a combination of the functions of a receiver and a user), an interface, an interactive process and the work itself (which is neither an artefact nor an interface). It is a work in which the property is not limited to the sphere of perception but conditions it itself, its ontic status and structure; a work truly interactive, displaying its properties and functioning only when the user behaves in an active way, using the object as a tool to achieve one's aims; a work created only in the process of reception and interaction, it is processual and lasts as long as the interaction develops and as long as the interactor decides to break the contact with the work. It is a work where not only a fully concentrated observation, contemplation or experiencing a catharsis from a secure distance matters but rather a work where a deed, a specific action influencing the object must be a response of a receiver. It is a form leading a receiver to a co-participation, joining a dialogue, not only on the level of interpretation but mainly in the sphere of actions; a form engaging not only the receiver's eyesight and hearing but often touch as well (Kluszczyński 2001: 85-99).

Feingold's work uses most of the expression means named by Kluszczyński. In spite of partly imitating a traditional medium with its appearance it is actually based on a computer carrier, uses a film, sound, a photo as well as written and spoken words (to be more specific: written

32 ttp://odra.okis.pl/article.php/371. Access date: 15.07.2012. 
words transported into their spoken version). The work constitutes a representation of multimedia art. It is related to and directly evolves from the development of computer technology (multimediality - a complex compound and multi-faceted communication with a computer). Kluszczyński suggests that it should be called interactive multimedia art or hypermedia art. The latter term draws attention to the hypertextual quality of a work which does not follow a linear order typical for textual structures but is based on a multi-level structure of a hypertext with a free multi-directional navigation through its numerous levels.It is worth mentioning that Kluszczyński distinguishes the so called classical kind of multimedia art as an effect of a broad understanding of a medium category (which may refer to each form of expression), art determined by co-occurrence of several different forms of artistic expression within one work. What is interesting, The Surprising Spiral is a link between the first and the second meaning scope of the discussed term. Its physical, tangible form imitating a book links it with the classical kind of multimedia art. One can not only read or hear it but also admire it. If not beautiful like a heavy, lavishly hardbacked book volume may be, the opening of which promises a surprise (what is more, it is exposed on a heavy wooden pedestal or a reading stand), it certainly is physically interesting and is able to catch a viewer's eye.

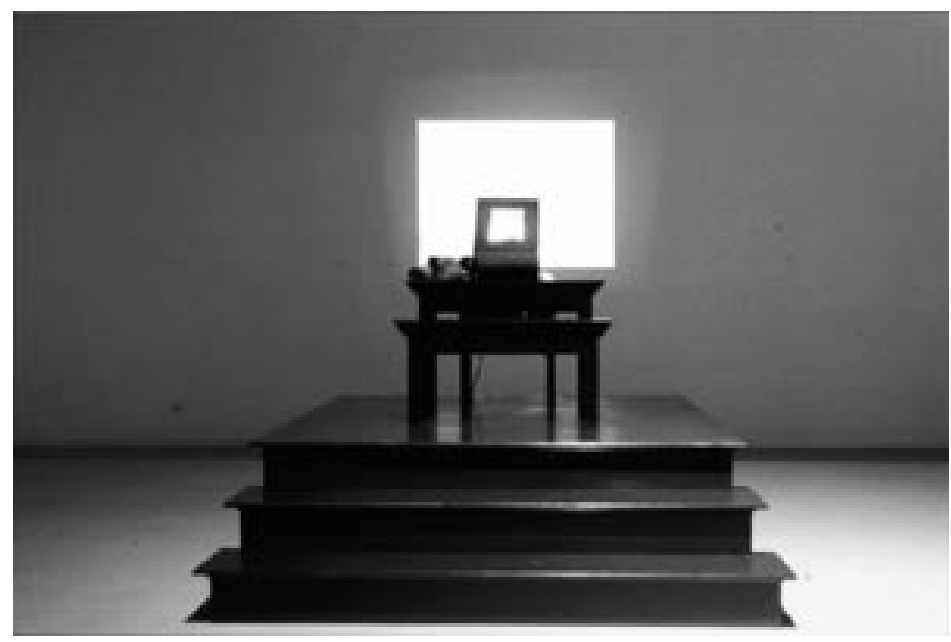

Photo 19. Ken Feingold, The Surprising Spiral (1991) ${ }^{33}$.

${ }^{33}$ Photo from the website of WWW Center for Art and Media ZKM in Karlsruhe: http:// on1.zkm.de/zkm/werke/SurprisingSpiral Access date: 15.07.2012. 


\section{An interactive reading in a gallery space?}

Here is the place where the question whether this is the future of literature should be asked. Will literature start moving towards literary representations characterising total works - material and textual at the same time, but also hypertextual, rhisomatic and media-like -according to the democratisation, digitalisation and the audiovisual nature of literary culture recently described by Maryla Hopfinger? Like The Surprising Spiral? The initiation has already happened and may cause the highlighting of a certain, one must admit, extremely interesting and promising trend in the area of contemporary art. The trend would undoubtedly change the amount of time the reader spends in a museum because one would enter the museum-gallery space not only to look but also to read. This is also because apart from The Surprising Spiral other examples of this type can be named, e.g. Text Rain (from 1999) by the duet Camille Utterback and Romy Achituv ${ }^{34}$ and Beyond Pages (1995), a work created by Masaki Fujihata ${ }^{35}$.

What is the real difference between Feingold and Fajfer? Both Fajfer and Feingold call for a holistic approach to work. In both cases we deal with not only a textual message but also with the significance of the physical constitution of the object and influence upon (and message derived from) the work. In the case of The Surprising Spiral it is simply a work (an interactive installation) using the physical and material character of an artefact and becoming an interface to a larger extent.

I am obviously aware of the risk lying in juxtaposing works belonging to such different creative environments as interactive art and e-liberature. Through this controversial juxtaposition I intended to attract attention to the fact that narrative works exist in the sphere of fine arts and literature and they constitute a clear example of new qualities emerging in effect of media and literature convergence. Both of them, however, and each one for a different reason, struggle against someone who wants to interpret them (The Surprising Spiral does so because it does not generate consistent narration and constitutes at most an artistic evidence for the world's textuality or intertextuality; in Fajfer - due to his overcontrolled and closed constitution both on the level of structure and content; cyber narrative poems (not mentioned in this article) - usually due to the limited amount of con-

\footnotetext{
${ }^{34}$ See e.g.: http://camilleutterback.com/projects/text-rain/. Access date: 05.09.2012.

${ }^{35}$ See e.g.: http://www.youtube.com/watch?v=flXXXhe9diY. Access date: 05.09.2012.
} 
tent). A demanding reader, receiver or interactor would expect a literary potential from the senses generated by them - a literary potential which might face the potential of the literary content of the culture of printing. As literature scholars we will have to stick to awaiting the emergence of a cybernetic work (which would find its place somewhere between The Surprising Spiral by Feingold, cybernetic poems by Bromboszcz and a content comparable to The Name of the Rose by Umberto Eco). So far, however, our appetites have not yet been satisfied.

Translated by Dorota Ślęzak

\section{Bibliography}

Bazarnik Katarzyna, Fajfer Zenon 2009, Oka-leczenie, Cracow: Korporacja Ha!art.

Bazarnik Katarzyna 2010, Liberatura czyli o powstawaniu gatunków (literackich), [in:] Z. Fajfer, Liberatura czyli literatura totalna. Teksty zebrane z lat 1999-2009. Korporacja, Cracow: Korporacja Ha!art.

Bodzioch-Bryła Bogusława 2006, Ku ciału post-ludzkiemu... Polska poezja po 1989 roku wobec nowych mediów i nowej rzeczywistości, Cracow: Korporacja Ha!art.

Borges Jorge Luis, The Book of Sand, trans by A. Hurley, http://www.annecoale.com/web4pics/bookofsand.pdf.

Eichenbaum Borys 1972, Problemy stylistyki filmowej, trans. B. Grabowska, [in:] Estetyka i film, ed. A. Helman, Warsaw, as cited, [in:] W. Osadnik 1986, Lingwistyka i filmoznawstwo. Krytyczna ocena tendencji lingwistycznej w badaniach nad filmem, Katowice: Wydawnictwo UŚ.

Fajfer Zenon 2010, W stronę liberatury, [in:] idem, Liberatura czyli literatura totalna. Teksty zebrane z lat 1999-2009, ed. K. Bazarnik, Cracow: Korporacja Ha!art.

Fajfer Zenon 2010,Liberature or total literature. Collected Essays 1999-2009, trans. and ed. K. Bazarnik, Cracow: Korporacja Ha!art.

Fajfer Zenon 2009, Spogladając przez ozonowa dziurę, Cracow: Korporacja Ha!art.

Filiciak Mirosław 2006, Wirtualny plac zabaw. Gry sieciowe i przemiany kultury wspótczesnej, Warsaw: Wydawnictwa Akademickie i Profesjonalne.

Godzic Wiesław 1984, Film i metafora. Pojęcie metafory w historii myśli filmowej, Katowice: Wydawnictwo UŚ.

Hartwich Dorota 2005, Litera na wolności: http://odra.okis.pl/article.php/371. Data dostępu: 15.07.2010.

Hendrykowski Marek 1994, Słownik terminów filmowych, Poznan: Wydawnictwo „Ars Nova”. Hopfinger Maryla 2010, Literatura i media. Po 1989 roku, Warsaw: Oficyna Naukowa.

Jakobson Roman 1989, O stosunku między znakami wizualnymi i audytywnymi, [in:] idem, W poszukiwaniu istoty jezyka I, ed. M. R. Mayenowa, Warsaw: PIW. 
Jakobson Roman 1972, Upadek filmu?, [in:] Estetyka i film, ed. A. Helman, Warsaw: Wydawnictwa Artystyczne i Filmowe, as cited, [in:] W. Osadnik 1986, Lingwistyka i filmoznawstwo. Krytyczna ocena tendencji lingwistycznej w badaniach nad filmem, Katowice: Wydawnictwo UŚ.

Jenkins Henry 2006, Convergence Culture, New York and London: New York University Press. Jenkins Henry 2003, Quentin Tarantino's Star Wars? Digital Cinema, Media Convergence and Participatory Culture; [in:] Rethinking Media Change. The Aesthetics of Transition, eds. D. Thorburn and H. Jenkins, Cambridge MA: MIT Press.

Jenkins Henry, Thornburn David 2003, Introduction, [in:] Rethinking Media Change. The Aesthetics of Transition, eds. D. Thorburn and H. Jenkins, Cambridge MA: MIT Press.

Jeżyk Łukasz 2010, Widzieć, wierzyć, wiedzieć. Dwadzieścia jeden liter Zenona Fajfera, [in:] Z. Fajfer, Liberatura czyli literatura totalna. Teksty zebrane z lat 1999-2009, Cracow: Korporacja Ha!art.

Kluszczyński Ryszard W. 2001, Światy multimediów, [in:] W świecie mediów, ed. E. Nurczyńska-Fidelska, Cracow: Universitas.

Lister Martin, Dovey Jon, Giddings Seth, Grant Iain, Kelly Kieran 2009, New Media: A Critical Introduction, London, New York; http://www.philol.msu.ru/ discours/images/stories/speckurs/New_media.pdf.

Manovich Lev 2006, Język nowych mediów, Warsaw: Wydawnictwa Akademickie i Profesjonalne.

Miczka Tadeusz 1995, Kino jako poezja optyczna. Próby futuryzacji kinematografu w Polsce w latach 1918-1939, [in:] Kino - Film: poezja optyczna? ed. J. Trznadlowski, Wroclaw: Wydawnictwo Uniwersytetu Wrocławskiego.

Nowakowski Radosław 2005, Koniec świata według Emeryka; http://www.emeryk.wici.info/

Paz Octavio 1974, Matpa gramatyczna, trans. Krystyna Rodowska; http://www.grupaphp. com/phpspiskiiplotki/sip008.php.

Preikschat Wolfgang 1994, Wideo jako metafora, [in:] Prędkość i przyjemność. Kino i telewizja w dobie symulacji elektronicznej, ed. A. Gwóźdź, Kielce: Wydawnictwo Szumacher.

Rek Jan 1994, Między filmem a literaturą. Szkic do portretu Łódzkiego Ośrodka badań nad filmem, [in:] Film: Obraz - Język - Wyobraźnia - Idea, ed. J. Trznadlowski, Wroclaw: Wydawnictwo Uniwersytetu Wrocławskiego.

Shuty Sławomir 2002, Blok; http://www.blok.art.pl/

Stern Anatol 1959, Film w poezji, [in:] Wspomnienia z Atlantydy, Warsaw: Wydawnictwa Artystyczne i Filmowe.

Tynianow Jurij 1972, Prawa kina, trans. B. Grabowska, [in:] Estetyka i film, ed. A. Helman, Warsaw, as cited, [in:] W. Osadnik 1986, Lingwistyka i filmoznawstwo. Krytyczna ocena tendencji lingwistycznej w badaniach nad filmem, Katowice: Wydawnictwo UŚ.

Zawojski Piotr 2005, Galaktyka post-Gutenberga, "artPapier", No. 12.

Zawojski Piotr 1998, Cyfrowe obrazy fotograficzne - pomiędzy bytem wirtualnym a rzeczywistym, [in:] Intermedialność w kulturze końca XX wieku, ed. A. Gwóźdź, S. Krzemień-Ojak, Białystok; http://www.fil.us.edu.pl/film-i-media/zawoj/PZCyfob.htm. Data dostępu: 15.07.2012. 


\section{Bogusława Bodzioch-Bryła}

\section{Other links}

http://www.zawojski.com/2006/04/19/galaktyka-post-gutenberga/

http://catalogue.nimk.nl/site/?page=\%2Fsite\%2Fart.php\%3Fdoc_id\%3D2813

http://on1.zkm.de/zkm/werke/SurprisingSpiral

http://oneartworld.com/artists/K/Ken+Feingold.html?atab=works\&image=2806

http://wro05.wrocenter.pl/thesurprisingspiral_pl.php.

http://www.culture.pl/baza-sztuki-pelna-tresc/-/eo_event_asset_publisher/eAN5/content/ wro-miedzynarodowe-biennale-sztuki-mediow.

http://www.medienkunstnetz.de/works/the-surprising-spiral/

http://www.newsweek.pl/Europa/jedno-pioro-jest-ptakiem,43818,2,1.html 